\title{
THE POLITICS OF FACE COVERINGS AND MASKS IN RUSSIA, FRANCE, AND QUÉBEC
}

\author{
Andrea Chandler \\ Carleton University
}

\begin{abstract}
Since 2004, governments in a number of countries have initiated tense political debates over the question of whether religious symbols should be permitted in public places. Frequently, such debates have focused on the head and face coverings worn by many observant Muslim women, as has been explored by a rich scholarly literature. However, relatively little has been written about the specific reasons why these laws have been adopted, and few cross-national comparisons have been made. This paper will examine the following cases: first, the law against wearing face coverings in France, adopted during Nicolas Sarkozy's presidency in 2010; and second, the extensive debates about access to government services for people wearing religious clothing in Québec (Canada). Finally, the paper will examine the distinct case of Russia, where high court decisions have revealed a reversal in the authorities' former tolerance of the wearing of head coverings in public places. Three variables help to explain why these laws came upon the political agenda in these admittedly very different countries. First, all three adopted previous measures to limit citizens' ability to don face coverings during political protests; second, these countries' choices influenced each other, showing the importance that global influences can play in policy formation; and finally, political leaders attempted to use laws on face and head coverings as a strategy to reinforce their power.
\end{abstract}


Author's note: This article is based on a paper presented to the 2014 Annual Conference of the Canadian Political Science Association, May 29, 2014, Brock University, St Catherines, ON. I am grateful to those who attended for comments. I thank the Office of the Dean of the Faculty of Public Affairs at Carleton University for funding to attend the conference. I also received valuable comments, especially from Melanie Adrian, at a presentation of the preliminary draft of this paper at a Research Seminar at the Centre for European Studies, Carleton University, February 12, 2014. Finally, I would like to thank two anonymous referees, whose suggestions helped me to improve the final version.

\section{Introduction}

Governments have suddenly become very interested in what people wear on their heads and faces. In the last ten years, countries as diverse as France, Bulgaria, and Russia have advanced new restrictions on the wearing of head coverings in public (Ghodsee 2007). This paper will examine government and legislative action on head coverings and masks in the following cases: first, the law against wearing the niqab or other face covering in France, adopted by the French parliament during the tenure of former president Nicolas Sarkozy in 2010; second, the province of Québec in Canada, which had lengthy legislative debates about the extent to which people displaying visible religious symbols - among them the hijab or niqab - should be able to receive government services. Québec's Liberal government retreated from relatively moderate proposed legislation in 2011, only to see its successor government, led by Parti Québécois leader Pauline Marois, advance the more controversial Charter of Québec Values (which ultimately failed to pass). Finally, the paper will examine the case of Russia, where judicial decisions by the country's Supreme Court have demonstrated a shift away from tolerance towards the wearing of head coverings in public places.

Why are governments seeking to adopt policies restricting the wearing of head and/or face coverings in public? As this paper will explain, it is puzzling that such different governments have considered these kinds of laws, even in the face of evidence that such policies have considerable negative consequences. Furthermore, it is surprising that these policies were initiated in very different kinds of societies by contrasting political regimes. Québec is a province within a liberal democratic federal system, France is a liberal democracy within a unitary state, and Russia is a country which has moved away from democracy under the presidency of Vladimir Putin. All of the cases chosen are secular states with multiethnic societies, including Muslim minorities. The countries however have different political traditions - Canada has a parliamentary system, France a semipresidential system, and Russia a legacy of strong state control. Furthermore, laws on head and face coverings were initiated by leaders of different political stripes. France's UMP and Russia's Vladimir Putin shared a right-wing political orientation, but operate in very different contexts. However, the Parti Québécois is situated squarely on the left of the Canadian political spectrum. Soft nationalism is the only common denominator among these three leaderships. So then why would leaderships in these countries that are so different be pursuing policies that are so similar? 
A second puzzling feature of these policies is there is no particular dramatic event or social change that seems to be inspiring them. As Jennifer Fredette argues with the case of France, certain powerful politicians and prominent intellectuals participated in a discourse that posited that headscarves were an indicator of a problem in the Muslim population, to be addressed with state action. However, more nuanced views of headscarves did not gain as much publicity in the media (Fredette 2014). Despite the tone of urgency with which policies on head and face coverings were introduced, there was no immediate pretext for them, and the rationales for government action were vaguely defined. The third puzzle is that legislative efforts to limit the wearing of head and face coverings led to unexpected negative consequences, as much of the literature suggests. Indeed, France's law could be credibly considered a policy failure. And yet the Parti Québécois attempted to put forth a law with strong similarities to the French model, even as that model was being challenged at the European Court of Human Rights. Why pursue a policy that has been heavily criticized elsewhere?

This paper offers two arguments, and an additional observation, which emerged from an analysis of the three countries' efforts. The first argument posits that there was a global "demonstration effect:" debate in these countries drew upon references to the models of other states. Politicians invoked ideas and arguments from other contexts in order to justify their own political plans. Once a law was adopted in one country, it became a model for others, even if that other country had a completely different social context. Oddly, however, the spread of these discourses did not seem to take into account whether a policy had been effective or beneficial when put into practice. The second argument is that these policies can be considered examples of "wedge politics." Wedge politics is a term used to describe situations where a political party or leader, in a competitive political system, adopts policies aimed at gaining the support of one part of the population, even if it alienates other groups. Wedge politics may drive leaders to pursue questionable policies in an effort to achieve a short-term political objective, such as to win an election. Finally, the research led to an observation: in all three countries, laws previously passed limiting the wearing of face coverings during protests were passed shortly before politicians staked strong positions against the wearing of head and/or face coverings. It is thereby hypothesized that laws against wearing masks during protests created a form of path dependency, facilitating the process of framing the wearing of face coverings as an act of defiance.

\section{Literature on the Politics of Head and Face Coverings}

Much of the existing literature on the politics of head and face coverings examines them in the context of governments' attempts to separate church and state. State campaigns aimed at ending veiling practices within Muslim communities are not a new phenomenon: such campaigns took place in Turkey under Kemal Ataturk, and in Soviet Central Asia, in the 1920s (Massell 1974, 218-20, 241-6). Such policies often were presented as efforts to free women from the social constraints of religion. John Bowen (2007) argued that France's fairly restrictive policies towards Muslim headscarves are a result of the way in which secularism ("laïcite") had become perceived as an accomplishment of the 1789 French Revolution. While secularism may provide 
protection against state encroachment upon religion, there are differing views on the extent to which secularism should affect individuals' behaviour in public spaces. For example, in some countries, individual women, girls or their families, have appealed to judicial institutions for the right to wear their headscarves within institutions, especially in schools (Ghodsee 2007, Shadid and van Koningsveld 2005).

As some scholars argue, political culture can play a strong role in determining whether differences of opinion over religion in the public sphere can be amicably resolved. A history of multicultural policies, a degree of consensus over the boundaries of religious expression, and strong judicial protections for minority rights, can prevent issues from becoming politicized. In a 1997 article, Sarah V. Wayland contrasted the cases of Canada and France in responding to appeals by individual students to wear religious symbols (respectively the Sikh kirpan and the Muslim hijab) to public school. In Wayland's analysis, Canada's history of religious pluralism and strong history of immigration contributed to an outcome that was more accommodating of students in hijab than France (Wayland 1997). In short, this first literature tends to see headscarf politics as disputes over balancing civil rights, which can be negotiated as part of a robust democratic process. However, as this paper will demonstrate, political leaders sometimes pursue politicized policies that vary considerably from judicial decisions on minority rights.

Why do headscarves and face coverings attract so much attention from parliamentarians in North America and Europe? Some authors argue that contentious assumptions about Muslims sometimes colour debates about social policy issues. Fredette (2014) argued that in France, elites often perceive Muslims as being a relatively similar group of people, rather than as diverse as any other group of French citizens. Furthermore, politicians may view a particular religion in ways that do not necessarily coincide with the perceptions of members of that religious community. As Abdolmohammad Kazempur argues (2014, 30), policy debates that advocate firm actions towards Muslims are often linked to what he calls the 'Muslim question': common, stereotypical beliefs, such as the idea that Muslim minorities are reluctant to embrace democratic practices. Such beliefs are not necessarily evidence-based; for example, a recent survey suggested that many people in Western countries think that the number of Muslims in the total population is much higher than it actually is (Ipsos-MORI 2014, 10). In the minds of authorities in some Western countries, headscarves have been considered a symptom of the social problems facing Muslim minority communities; some leaders assume that headscarves pose a barrier to women's full participation to public life (Adrian 2011, 411-22). Emma Tarlo (2010, 132-4) argues that suspicion towards the face veil controversy reflects Western mentalities, insofar as the use of the face for communication is important in European culture, and because masks have historically been seen as either playful or ominous.

Another literature points to the importance of the global context, in which the tragic events of September 11, 2001 contributed to a fear of Muslim fundamentalism in the Western world. In the context of 9/11, some saw this fundamentalism as a threat to liberal democracy (Kaya 2012, 399-401). This discourse at times was simplistic, as Islam was not always well understood by Western political leaders (Afshar 2013, 10-12). In this context, a hijab or niqab became perceived by some as an indicator of a rejection of the West. As Mel Chen argues, burqas became seen as a symbol of women's oppression, 
while unease about face coverings drew on a theme in Western popular culture where "bad guys" are often depicted wearing masks (Chen 2012, 79-86). In some studies, Muslim women reported that after September 11, women wearing hijab faced greater discrimination than previously (Reeves, McKinney and Azam 2013, 59; Ahmed 2011, 207, 221). At the same time, globalization also influenced the decision to wear the hijab; Kristen Ghodsee argued that increased contact with the Middle East since the collapse of communism influenced the increased prevalence of austere Muslim dress in Bulgaria (Ghodsee 2010, 161-3).

In this context, the headscarf and face covering became symbols of the uneasy relationship between Islam and the Western, or European, state. Scholars have tried to reclaim the agency of Muslim women who wear head coverings, in order to contribute to more accurate knowledge of those who share this identity. Although not all observant Muslim women cover their heads, those who do are particularly affected by requirements that religious affiliation not be made visible (Leane 2011, 1033-4, 1060). A number of studies on Muslim women in Western countries have shown that those who cover their heads or faces do so out of personal choice, for a variety of reasons. Even the wearing of a veil, such as a niqab, does not necessarily indicate either a strict interpretation of Islam. Rather, it may be an expression of identity, or a rejection of the excesses of Western fashions (Borghée 2012, 43, 136, 166-9; Ahmed 2011, 120-23).

These literatures regard the headscarf issue as a political controversy. Two principles collide: the state's obligation to protect the individual's freedom of religion clashes with the idea that the state must be a secular space in order to ensure neutrality towards diverse social groups. But controversies over headscarves cannot be seen only as philosophical debates. In a competitive political arena, legislators' incentives to gain or keep power may outweigh the desire to represent minority citizens. One must consider, then, whether laws on face and head coverings serve a political purpose. To date, relatively little has been written about the political reasons why these policies are adopted.

A useful concept is the term "wedge politics," which came into use to describe certain strategies attributed to Republicans in the United States and Conservatives in Australia, among others. Shaun Wilson and Nick Turnbull define wedge politics as an overt planned effort to win political support by calling attention to sensitive, polarizing political issues, which often isolate one particular group of people. (Wilson and Turnbull 2001, 386, 390). Another term for the same basic phenomenon, "issue politics," is when politicians take strong stands on hot-button issues such as abortion and immigration (Nicholson 2005, 134-6). Wedge politics strategies have become more prevalent as politicians have used social media and electronic polling to try to precisely pinpoint pockets of receptive voters (Hillygus and Shields 2008, 184).

Although politicians who use wedge politics tend to believe strongly in its advantages, it is not clear whether politicians win because of those strategies, or in spite of them (ibid, 189-90). Indeed, the analysis of Nicholson (2005, 134-39) showed that wedge politics often fail, because they underestimate the sophistication of voters and miscalculate the potential for backlash. Wedge politics may backfire if a party's harsh rhetoric actually mobilizes opposition to defeat the wedge party (Jeong, Miller, Schofield and Sened, 
2011, 524). A similar argument was made by Maddison (2006, 433-4), who argued that wedge politics are particularly ineffective in countries with multiparty (rather than twoparty) systems. However, the literature suggests that wedge politics can change political discourse and beliefs over time, even if they do not necessarily lead to short-term political victories (Jeong, Miller, Schofield and Sened, 2011, 524; Wilson and Turnbull, 2001, 401).

This paper will argue that the logic of "wedge politics" helps to explain why France and Russia adopted policies on head and face coverings, while Quebec's attempt to establish these policies failed. In France, Nicolas Sarkozy won the presidency in 2007, a victory that was credited in part to a use of strident rhetoric on issues such as immigration and reducing the welfare state. This rhetoric, arguably, helped draw voters who might have otherwise been tempted by the extreme right Front Nationale (Nadeau and Lewis-Beck 2007, 55). However, once in power, Sarkozy continued to use wedge policies, which included policies perceived as tough on migrants and rhetoric unsympathetic to Muslim minorities (Gougou and Labouret 2013, 281). The ban on face coverings, insofar as it was couched in the effort to preserve French values, could be seen as a wedge politics strategy, as it seemed to cast the issue so that the opposition Socialists would have to take a stand either for or against veils. Public opinion can provide incentives for particular parties to pursue policies on issues related to Islam. A comparative study, surveying people from a variety of countries, found that left-leaning voters think much more highly of Muslims than those who identify with the right (Pew Research Center 2014, 30-2).

By looking at the politics of face and head coverings across these three cases, we can potentially learn about the limitations of wedge politics. While some politicians seem convinced that wedge politics work, more needs to be known about the instances in which wedge politics fail. For example, Sarkozy's defeat at the polls in 2012 suggests that wedge politics may be less effective for incumbents than it is for those seeking power. The case of Russia is also instructive, as this former budding democracy has again reverted to authoritarianism under the presidency of Vladimir Putin. While we typically associate wedge politics with competitive liberal democracies, the Russian case suggests that authoritarian regimes make use of this technique as well, although they may use it in a different way.

\section{France}

In France, political controversies over whether it was appropriate to wear Muslim head and face coverings in secular spaces date back to the 1990s. In 2004, a law was passed that prohibited the wearing of religious symbols in schools, which included the wearing of hijabs and other head coverings associated with religion. As John Bowen argued, Muslim headscarves became seen at that time, especially by right-wing politicians as a vague, but growing threat to the separation of church and state. At the same time, some Muslims were becoming more assertive in advocating for their rights to practice their religion (Bowen 2007, 83-4, 91, 197-8). Two young Muslim women appealed (unsuccessfully) to the European Court of Human Rights, claiming that the prohibition on wearing a headscarf at school violated their right to religious freedom. ${ }^{1}$ The 2004 law led 
some girls to stop attending public schools (Borghée 2012, 147). However, one researcher who interviewed Muslim women in a Paris suburb said that many did not object to that particular law, which confined restrictions on the headscarf primarily to schools and government offices (Selby 2012, 90).

Under the presidency of Nicolas Sarkozy, the debate on coverings advanced again, this time raising the issue of the wearing of face coverings (such as the niqab). At issue was not just whether faces should be uncovered in order to receive government services, but whether faces should be uncovered in all public places, such as streets, stores or markets. Subsequently, the French parliament (in which at that time Sarkozy's party, the UMP, had a majority), established a mission of inquiry into the wearing of face coverings (voile intégrale) in France. Presided over by André Gerin, the report was released in January 2010.

The lengthy report was based on hearings, written submissions, and feedback solicited by the parliament. On the one hand, it declared that French Muslims should be supported. On the other hand, the report came down quite firmly against the niqab, considering face coverings to be inconsistent with gender equality and a potential threat to society, insofar as they were presumed to constitute reluctance on the part of the wearer to interact with other citizens (Gerin 2010, 19, 23). It was written that the veil was not compulsory in Islam and that it was new to France (ibid, 31). The report expressed the concern that males were pressuring their female family members to wear veils (ibid 53-5). Interestingly, the report made reference to the province of Québec, which was at the same time preparing to debate a law defining the parameters of "reasonable accommodation" on the basis of religion. However, the report rejected that "très libérale" Canadian approach, saying that accommodation could lead to ever-increasing demands (Gerin, 2010, 64-7). Finally, the report voiced the idea of banning the wearing of the veil in all public places, although in fairness, it noted that there were valid concerns about whether such a ban could encroach upon individual freedoms (Gerin 2010, 92). Although the report claimed to be aggregating many different views, it was critical of the veil from the beginning. Indeed, the Gerin Report was criticized for insufficient consultation with French Muslims (Adrian 2011, 419).

The Gerin report served to frame the subsequent discussion of veils in the French legislature. In April 2010, the legislature passed a resolution criticizing the wearing of a veil as a "radical practice" which was inconsistent with the values of the French Republic, but also stating that the state would actively address discrimination and inequality. ${ }^{2}$ A few weeks later, draft law 2520, to prevent the wearing of the veil in public, was introduced in the parliament by Minister of State Michèle Alliot-Marie. ${ }^{3}$ The impact study presented to the parliament in May began by stating that citizenship requires face-to-face contact with other people within "public space" (l'espace public), and referred to wearing of face coverings as "dissimulation" (concealment). The niqab was said to be inconsistent with gender equality. The study went so far as to call the wearing of the veil a "symbolic act of violence," ("porteuse d'une violence symbolique qui déstabilise le contrat social"), creating a security problem because it made the wearer difficult to identify. While alternatives to a ban were discussed, the study claimed that a 
ban on covering the face would be consistent with other European countries and with rulings of the European Court of Human Rights. ${ }^{4}$

Thus, we can see that from the outset Law 2520 was framed in strong terms. Those who proposed the ban saw veils as a challenge to the French values affirmed in the 1789 Revolution. It was assumed that those who wore the veil rejected French society. However, studies have shown that very few women resident in France wear the veil. Furthermore, those who wear it generally see it as their personal choice, do not necessarily wear it every time they go outdoors, and are overwhelmingly Frenchspeaking French citizens (Borghée 2012 43, 38-9, 71; Bowen 2007, 70-2.) As Elaine R. Thomas argues, the headscarf laws in France juxtapose two different ideas of citizenship: one in which citizens are obliged to present themselves openly in public, and one in which citizenship means being included in society (Thomas 2012, 49).

The law was adopted in the National Assembly of the French parliament in July of 2010, after passing through three readings in less than two weeks. In the first reading, Michèle Aliot-Marie, the Minister of State who introduced the law, stressed the importance of the law for maintaining "the will to live together" ("la volonté de vivre-ensemble"). Another defender of the law, Jean-Paul Garraud, argued that it would be inconsistent to oppose the Taliban while condoning the wearing of the veil in France. Arguments were also voiced that the ban would promote gender equality. However, Jean Glavany, from the Socialist opposition, criticized the idea of banning the veil as too heavy-handed, and expressed the fear that it could promote social tensions and "fear of the other". Other opposition politicians expressed similar concerns, seeing the law as a manifestation of "Sarkozyism," and raising questions about whether the law infringed upon individual freedoms. ${ }^{5}$ As debate on the law continued, critics (primarily Socialists) argued that what was needed was greater social inclusion, not banning the veil. But André Gerin (of the Gerin report) argued that the law was a stand against increasing radicalism. An attempt to amend the law to confine its application to places where the government offered public services failed. ${ }^{6}$ By the third reading, debate followed similar lines, and the law was passed, with the UMP providing most of the support. ${ }^{7}$ In the Senate, defenders of the law noted that the law would especially penalize those who tried to compel others to wear the veil, and noted that a six-month period before implementation period would allow public education to take place. But again, critics argued that it was contradictory to claim to be passing a law that was in the interests of women's equality, and yet which would impose penalties primarily on women. A Socialist deputy raised the delicate question of how women would be compelled to remove garments which, in some cases, might cover the entire body. Nonetheless, the law passed the Senate. ${ }^{8}$ The law survived a challenge addressed to the Constitutional Council, and took effect in $2011 .^{9}$

Once implemented, the law proved to be unpopular and difficult to enforce (Chrisafis 2011). Police were reportedly often unwilling to apprehend alleged violators of the law, and the law's purpose was called into question by the fact that some women were being fined repeatedly under the law while no men ever had (Camus 2014). In 2013, the European Court of Human Rights announced that its Grand Chamber would hear a complaint about the law lodged by a Muslim woman who claimed that her right to privacy and religious freedom were violated (European Court of Human Rights 2013). In 
the end, the Court did not uphold the woman's complaint, noting that the proper balance of religious freedoms with other democratic principles depends upon a country's historical and social context, and observing that the law did not explicitly discriminate against Muslims. However, the Court's ruling was complicated, insofar as it demonstrated skepticism towards the government's claims that the law served gender equality, and expressed concerns that the law primarily affected one particular group (Muslim women). ${ }^{10}$ In July 2013, riots were reported in Trappes, outside of Paris, allegedly after police asked a woman wearing a niqab to show identification (Chrisafis 2013). In France, the parliamentary debate on the headscarf law showed a hardening of positions. Proponents of the law depicted it as an attempt to cope with a growing problem, but did not define what the problem was. Nor was there much evident consideration of how encounters between police and veiled women might take place.

If the ban on face coverings was an attempt by Gaullists to use "wedge politics," in order to court the support of far-right sympathizers and to embarrass the Socialists, it was unsuccessful. In 2012, Sarkozy was defeated as president, as was his political party (the UMP) in parliamentary elections. The face covering ban itself was not a prominent issue in the election campaign. Among the factors that experts considered responsible for his defeat, was the idea that Sarkozy's wedge politics had actually provoked some centreright voters to vote Socialist, while failing to win over Front National sympathizers (Gougou and Labouret 2013, 295-6; Nadeau and Lewis-Beck 2013, 64) One scholar argued that the French experience showed that while "cultural" issues such as immigration were important to French voters, in 2012 they were more important to leftleaning voters, while right-leaning voters were more concerned about the economy (Tiberj 2013, 83-4) Furthermore, Sarkozy failed to galvanize new potential supporters into voting, as voter turnout was lower in 2012 than in the previous electoral cycle (Muxel 2013, 209). Thus, with a sound defeat at the ballot box, and a return to power for the Socialists, Sarkozy's use of wedge politics was a questionable choice. It is paradoxical, then, that Québec's Parti Québécois would subsequently try to adopt a similar wedge policy a year later, shortly before calling an election which the party would ultimately lose.

\section{Québec}

After France's uncomfortable experience, Québec politicians could reasonably draw the conclusion that an extreme policy on face coverings was inadvisable. Indeed, Québec's provincial government initially adopted a relatively moderate approach. In 2010, the Liberal government initiated a draft law, Bill-94, on "reasonable accommodation." The law was not directed explicitly at headscarves or face coverings. Instead, its intent was to provide a clearer definition of the extent to which government offices would be expected to accommodate requests, made on the basis of religion, for accommodation in the delivery of government services. The draft law stated that government employees, including those working in educational institutions, health care, and public child care institutions, had to show their faces while working. ${ }^{11}$ Thus, the emphasis in the discussion, from the beginning, was not about how to regulate social behaviour in the public at large, but how to define when exceptions could be made in general government 
regulations. Therefore, with the focus on the government's limits and capacities, rather than on Muslims per se, the draft law was framed in a way that was less politicized than that of France.

The debate on the law, however, took place in a social context of controversy over religious accommodation. As Daiva Stasiulis argued, there has recently been social tension in Québec over immigration, as well as concern about Islam. While this disquiet is not necessarily distinct from that found in the rest of Canada, what makes Québec different is the strong will among the francophone population to maintain the Frenchlanguage identity (Stasiulis 2013, 191-5). In previous years, a number of disputes in Québec had inspired media attention and public debate. For example, a case where Muslim girls were allegedly sent home from school because they were wearing hijab led to a complaint to the Québec Human Rights Commission, which ruled against the school (Wayland 1997, 545-61). In another controversy, a town, Hérouxville, apparently adopted a "Code of Conduct," which among other things prohibited the wearing of face veils, and the stoning of women (CBC News 2008). These and other controversies were perceived as demonstrating misconceptions about immigrants and Muslims (Stasiulis 2013, 202-3).

In 2007, Québec's Premier Jean Charest tasked two prominent academics, Gerard Bouchard and Charles Taylor, with forming a commission to hold public hearings on the question of reasonable accommodation. The hearings were tense at times: however, in contrast to the Gerin mission in France, Bouchard and Taylor did not assume in advance that there was a serious problem with respect to ethnic relations and religious accommodations. In their report, Bouchard and Taylor argued that the evidence showed that most disputes were resolved amicably, without resort to the courts (Bouchard and Taylor 2008, 18). Bouchard and Taylor argued that although most disputes were resolved, there was a problem of perceptions, insofar as some francophones feared that immigration might put gender equality and the separation of religion and state at risk. These perceptions were sometimes based on incomplete information: people heard about controversies that erupted over religious accommodation, but did not always learn when these controversies ended in a mutually agreeable outcome (ibid 18, 71-4). The authors' main recommendations included the following: an insistence that any accommodations should observe the principle of equality; a commitment to educating males and females together, while permitting head coverings of a religious nature to be worn in schools; an affirmation that accommodations should be considered to require dialogue and compromise from all sides; allowing empty rooms in public buildings to be used for prayers, upon request; and accommodations should be considered in the spirit of making people feel part of a community rather than as outsiders (ibid, 20-1). The two academics also called for more assistance to immigrants in finding employment and learning French, and for government and school staff to have a better understanding of diverse cultures (ibid, 23). So like the Gerin commission in France, the Bouchard-Taylor commission recommended that education was very important in reducing social tensions, and they also explicitly raised France as an example not to be emulated: in their view, banning headscarves in schools contradicted the principles of learning and inclusion which were essential to the school's enterprise (ibid, 20). 
In 2010, Québec's Minister of Justice, Kathleen Weil, introduced Bill-94, positing that its goal was to provide clearer guidelines for government bodies to determine when to grant accommodations. ${ }^{12}$ Evoking the same phrase as had been used in the France debate, Weil argued that bill 94 would be helpful "pour mieux vivre ensemble" (to live together better). Weil, and her fellow Minister of Communications Denise Beaudoin, emphasized the large amount of public consultation that had preceded the law. ${ }^{13}$ Some deputies, however, expressed the view that the law did not provide a concrete guide for resolving disputes, and that it was directed primarily at one group. ${ }^{14}$ The bill was adopted in first reading on February 15, but narrowly 56 for, 46 against. ${ }^{15}$ Those opposed were members of the Parti Québécois and the Coalition Avenir Québec. ${ }^{16}$

Subsequently, there was a process of consultation in which experts and social groups were able to present comments on the law. For example, the Québec Council on the Status of Women's submission expressed concern about whether it was appropriate to pass a general law on issues that could be decided on a case-by-case basis on the basis of rulings by human rights tribunals. The Council also posited that there was a need for a broader debate on secularism, and was concerned about the possibility that government employees might be permitted to wear religious symbols. ${ }^{17}$ In contrast, the Federation of Canadian Muslims was opposed to the law because they thought it was overly directed towards Muslims and towards the niqab. The Federation argued that what Muslims needed were policies to help Muslim women find employment, to gain equal opportunities and to improve their social position. ${ }^{18}$

These views were echoed in the legislature's Commission on Institutions, which examined the draft law in 2011. From the beginning, committee members expressed concerns about whether such a simple law could serve such a complex intended purpose definitively. One deputy asked whether the main purpose of the law was to require women to remove their face coverings when in public, implying that a law primarily directed at women could be perceived as unfair. ${ }^{19}$ In subsequent meetings, deputies expressed concern about how to define various terms, even how to define religion. ${ }^{20}$ As one deputy put it, the bill was "anemic" (anémique) and was concerned that if passed, it could oblige individual institutions to provide accommodations that might overextend their capacities. The Council on the Status of Women's reservations were referred to repeatedly by the commission. ${ }^{21}$ In defence, Minister Weil said that Bill 94 would be "un geste d'interculturalisme" (a gesture of interculturalism) that would provide helpful guidelines for frontline government staff. ${ }^{22}$ As commission meetings continued, the same deputies tended to speak to the same points as before, and increasingly argued in favour of reinforcing the values of gender equality and secularism as declared in the draft law. ${ }^{23}$ One deputy expressed concerns about whether abortion rights could be affected if religion gained more influence; later, another deputy asked what the impact might be on gay and lesbian rights. ${ }^{24}$ On May 18, the Commission of Institutions considered, but did not vote on, an amendment to read: "Un accomodement pour motif religieux doit respecter le principle de laïcite de l'Etat" ("A religious accommodation must respect the principle of the secularism of the state"). ${ }^{25}$ The Commission held its last meeting on the bill on September 28, and that ended the discussion of the bill, which was not further pursued in the legislature in that form. With no firm consensus on the merits of the law, and doubts about its effectiveness, the Liberals did not pursue it further. Although the 
debate in Québec had some similarities to the debate in France, at that time no deputies called for the sort of law passed in 2010 in France. The Québec debate eventually became, to a considerable extent, a matter of jurisdiction. Was it appropriate for the provincial legislature to be passing a law on this issue? Or was it a matter for particular institutions, the judiciary, or simply human dialogue to resolve?

In 2012, the Liberals lost a provincial election, bringing to power the Parti Québécois (PQ), which revisited the issue of head and face coverings in mid-2013 with the proposed Charter of Values. The draft Charter was approved for the legislature's agenda on November 7, 2013, although the Liberal opposition had already expressed concerns about the Charter as early as October $23 .{ }^{26}$ Members of the PQ presented the Charter as an affirmation of secularism as a fundamental Québécois principle. However, the Liberal opposition claimed that the introduction of the bill was aggravating discord between Quebecers, and was attempting to reinvent state-society relations in a way that would adversely affect religious freedoms. ${ }^{27}$ Members of the other opposition party, the Coalition Avenir Québec (CAQ) also criticized the PQ's draft Charter, as they had their own alternative Charter to offer. ${ }^{28}$ Given the small size of the CAQ, however, the bill had little chance of passing.

The Charter declared a broad range of public employees that were expected to refrain from wearing obvious religious symbols, and to show their faces, in the course of their work. These groups included civil servants, at the provincial and municipal levels; but also those who worked in provincially-funded institutions, such as health care practitioners, teachers, university employees and child care providers. Members of the public who were clients of these services were generally expected to have their faces uncovered as well. The Charter stated that members of the public could request religious accommodations, but institutions could grant such accommodations only if they met specified criteria. ${ }^{29}$ The Charter thus covered a very broad scope, and limited public institutions' discretion to provide accommodations. The Charter did not specify the consequences of violating the Charter, or who would determine whether a violation had occurred. Therefore, there was potentially a great deal at stake for those who regularly wore religious symbols. The opposition Liberals noted that the Charter therefore directly affect over 600,000 people whose employment was covered by the Charter, and called attention to the many public figures and groups who had expressed concerns about the Charter even before it had been introduced. ${ }^{30}$ The National Assembly held hearings on the bill, where a variety of individuals and groups expressed their views to the Commission on Institutions. However, the bill was never passed, as it was abandoned when the Liberals defeated the PQ in the spring 2014 provincial election.

The PQ's Charter seemed at odds with a recent Canadian judicial precedent. In 2012, Canada's Supreme Court issued a ruling on a dispute involving a woman, who had been denied in her request to wear a niqab in court to give testimony about an alleged assault upon her. The court accepted that it could adversely affect the rights of the defendant if he and his lawyers were not able to see her face in the courtroom; however, the Court called upon the judge to make efforts to see if an alternative resolution of the issue was possible before requiring the witness to remove her niqab. ${ }^{31}$ The Court's decision seemed 
to suggest that appropriate grounds for religious accommodation were highly contextual, depending on the particular circumstances.

The Charter seemed to be a wedge issue for the PQ, as Premier and Marois's government continued to pursue the Charter despite its evocation of considerable opposition. Indeed, Marois called a provincial election not long after introducing the Charter, even though hearings on the bill had been well underway. The introduction of the Charter in the legislature had given the opposition Liberals an opportunity to deliver long speeches in favour of human rights and social inclusion, which gained considerable media attention. In April 2014, the Parti Québécois lost the election to the Liberals, a defeat that analysts attributed in part to opposition to the Charter (Hébert 2014, Wells 2014). Wedge politics, arguably, had failed again, as they had in France.

\section{Russia}

As an authoritarian regime, Russia's situation is quite different from the previous two cases; in states where elections do not meet the liberal democratic standard of fair competition, wedge politics do not serve the same purpose as in Québec or France. However, we should not assume that authoritarian polities do not use wedge politics; they may instead use them to try to court populist support and to weaken a fledgling opposition. The Russian case is interesting in its abrupt reversal of a previous position. A controversy in 2013 led the Supreme Court to deviate from its previous position, and the Russian position limiting headscarves in schools invoked the French precedent even while the country's leadership were otherwise arguing that "Western" democratic practices were not applicable to Russia.

Islam has been a prominent faith on Russian state territory for centuries, but under the Soviet regime (1917-91), the state officially embraced atheism. Officially religions were still allowed to exist, but they were under the tight control of the state. After the collapse of communism, religion began to be practiced more openly, and there was a growing interest in Islam among Muslim communities in the North Caucasus and the Volga regions. A separatist government took power in the republic of Chechnya, and two civil wars broke out in the Russian government's effort to restore the republic to federal control. In the late 1990s and early 2000s, several bombings in Russia were attributed to Chechen terrorists. In the hostage-taking at the Nord-Ost theatre in Moscow, the media showed attention of veiled Chechen women among the hostage takers, developing a media stereotype of a female fundamentalist (Stack 2011, 83-95). Concerns over security at the 2014 Sochi Winter Olympics drew renewed media attention to the fear of possible Muslim female suicide bombers, or "black widows" (for example Associated Press 2014). Chechens were often negatively depicted in the media as "bandits," who sometimes covered their faces (Eichler 2006, 489-90, 498). In Chechnya, under the presidency of Ramzan Kadyrov, there has been a campaign to encourage women to wear headscarves as a sign of adherence to Muslim traditions; a Human Rights Watch publication $(2011,11-4)$ criticized the policy for pressuring women and girls to cover their heads. 
However, officially, the Russian federal government did not take steps against head or face coverings. In 2003, several women complained to the Supreme Court about regulations that required individuals requesting passports to submit photos with uncovered heads, claiming that this rule violated their right to practice their Muslim faith. Initially, the Supreme Court turned down the complaint, noting that Russia was a secular ("svetskii") state and the rules were not specifically directed towards Islam; procedures, in the Court's view, must apply equally to all individuals. ${ }^{32}$ Two months later, though, the women won their case upon appeal. One of the Supreme Court's collegial bodies ruled that the women should be allowed to be photographed with covered heads, in order to respect their right to choose their religion; said the judges, constitutional rights could be limited only through federal laws, and not by a government regulation. ${ }^{33}$ Hence, the court took a stance of religious tolerance. Perhaps this is because Russian women, especially of the older generation, have long worn colourful headscarves. With the revival of Orthodox Christianity in recent years, some Russian Orthodox women have adopted a modest style of dress which includes a scarf covering the hair (Kizenko 2013, 607). So in Russia, wearing a scarf on the head is not necessarily seen as a sign of Muslim identity.

In 2013, two events occurred that put the issue of women's face coverings at the centre of political controversy in Russia. The first was the trial of three activists of the feminist punk-rock art collective, "Pussy Riot." The three young women were arrested for alleged criminal hooliganism after an incident at Moscow's Cathedral of Christ the Saviour, where they had performed a brief dance, which later appeared as a rock video with lyrics critical of Vladimir Putin and the Orthodox Church. A major issue in the trial revolved around the brightly coloured clothes and balaclavas that the girls were wearing. The masks were an issue for two reasons: first, they were a key part of the case, because the judge was persuaded that masks were inappropriate to wear in church. The girls were said to have entered the cathedral with their heads (but not faces) covered in the manner of Orthodox tradition, which the judge interpreted to mean that they knew what the standards were. Second, the judge ruled that the masks were worn in order to conceal identity. ${ }^{34}$ The women's defence posited that the masks served an artistic purpose, saying that they had performed on Shrove Tuesday (Maslenitsa), when it is customary to wear costumes (Alekhina 2012). In the trial, a key issue was that women were expected to cover their heads in church, but it was unacceptable to cover both head and face. Shortly after the Pussy Riot verdict, seven women in balaclavas were reported to have been arrested in France under France's 2010 law on face coverings. The women were apparently protesting the Pussy Riot verdict at the Russian consulate in Marseille (Chrisafis 2012).

The second controversy was a court case in the region of Stavropol' in southern Russia, where a local schoolteacher was reported to have refused to allow girls in hijab to attend class, and where the school subsequently imposed a uniform which excluded the hijab (Barry 2013). Parents appealed the ban in court, but the appeal was dismissed (RAPSI, 2013). A regional court ruled that schools had the right to impose dress codes to maintain order, and as appropriate to a secular institution (Fedosenko 2013). The Stavropol case gathered nationwide attention. A new education law passed in the Russian parliament in December 2012 stated that schools had the right to establish their own dress codes. ${ }^{35}$ President Putin himself weighed in on the issue, saying in December 2012 that there was 
no tradition of hijabs "in our culture," and "why should we introduce traditions that are foreign to us?"36 A few months later, Putin opined that hijabs had already been banned in some Muslim countries and in France, and that he favoured the idea of a school uniform. ${ }^{37}$ In July of 2013, Russia's Supreme Court rejected an appeal on the Stavropol' school decision, arguing that by law Russia's schools were secular and school uniforms ensured the neutrality of schools towards religion. The Court opined that the rights of one group could not be privileged over other groups, implying (but not elaborating) that religious forms of dress had an adverse effect on those who were not members of that group. The decision also cited decisions of the European Court of Human Rights on complaints in France and Turkey, thereby revealing an attention to international decisions. Finally, the Court ruled that home schooling and religious schools were options for children who wore headscarves. ${ }^{38}$ The Court also cited a Russian government document that claimed that wearing head coverings in school could spread diseases. That document, coincidentally, was dated November 2012, just as the headscarf issue was heating up in Stavropol' krai.

The headscarf issue subsequently entered the arena of federal politics: on December 18, 2013, the Duma passed in its first reading an amendment to the law on education which stopped short of mandating a single school uniform for all of Russia, but which would require Russian regional, republic and krai governments to establish a school uniform within their respective jurisdictions. ${ }^{39}$ School uniforms were presented as a way to establish an orderly learning environment; however, the desire to limit the wearing of religious symbols in schools was presented as the second major rationale for the draft law. The deputy from the "United Russia" party who presented the law in the Duma discussed the Stavropol' case as "a scandal." She argued that those, Orthodox or Muslim, who wanted to cover their heads could do so on evenings and Sundays. ${ }^{40}$ Legislation, she argued, would enable regions to establish uniforms appropriate to their conditions. A deputy from the Liberal Democratic Party of Russia (LDPR, a nationalist party) argued that the Stavropol' contretemps was about "the expansion of a particular radical direction of Islam." "41 After passing in the first reading, the bill was passed in the Duma with little discussion in May 2014, and was signed into law in time to take effect for the 2014-2015 school year. ${ }^{42}$

Arguably, one reason for Russia's apparent about-face on headscarves was the previous passage of a law which included measures on the wearing of face coverings during demonstrations, as part of a series of new restrictions on opposition political activity. In 2012, Vladimir Putin had returned to the Russian presidency, but only following large protests in response to parliamentary elections in 2011 and the presidential elections of March 2012. An opposition movement formed, voicing allegations of electoral irregularities (Wood 2012, Wolchik 2012). Subsequently, a series of laws were passed that indicated that the regime intended to tighten its power. Among the laws passed was a law increasing penalties for unauthorized protest activity, including the wearing of masks during demonstrations. In the debate on the law, masked protesters were discussed as "lowlifes" ("mertsavtsy"). ${ }^{43}$ Another law, passed in the spring of 2013, included in the Criminal Code more explicit definitions on the criminal offence of insulting religious feelings, which was introduced in parliament as being inspired in part by Pussy Riot. ${ }^{44}$ The idea was that masks could be used by vandals and "hooligans" in order to conceal 
their crimes. It is interesting, though, that in the debate on masks, those who wore them were perceived as acting on their own volition, whereas those girls who wore hijabs to school were assumed to be obeying their parents. In donning balaclavas, Pussy Riot were perceived by the prosecutor and judge in their trial as acting deliberately, to reject the Orthodox head scarf that was considered appropriate to wear in a cathedral. The Russian case showed that in some contexts it was considered necessary to wear an item of clothing that was forbidden in another context, and women seemed to be the object of these confusing, shifting prohibitions.

\section{Analysis of Findings}

The Russian case raises the question of path dependency: to what extent were laws on face coverings made possible by previous legislation? Once covering the face during a protest was framed in law as a punishable act of civil disobedience, it created a discourse in which face covering itself could be more readily seen as an act of political defiance. Turning to the cases of France and Québec, we can see that in those countries, acts were passed to limit the covering of the face during political protests, and that these acts occurred prior to France's 2010 niqab ban and the PQ's introduction of the Charter.

Part of the context for debate over face coverings is the occurrence of new forms of protest movements, in which clothing can make a statement about one's political views (Tarrow 2011, 151-3). Radical political movements, such as the Occupy movement, have gained more attention in recent years (Kaldor and Slechow 2013, 78-99). In 2009, the French government issued a decree that banned the "illicit" covering of the face during demonstrations that threaten public order. The decree said that it did not apply to faces covered for a "good reason" ("motif légitime"). ${ }^{45}$ Although the decree was directed at masked protesters rather than the niqab, the decree set an expectation that people be expected to show their faces in public.

In Canada's federal political arena, face coverings became a political issue in a different context. In response to intense and prolonged student protests in Montreal in the spring of 2012, the local city council had passed a bylaw making it an offence to cover one's face during a public demonstration "without a reasonable motive."46 In June of 2013, Canada's House of Commons, dominated by the Conservative Party and its Prime Minister Stephen Harper, passed a law, Bill C-309, which banned the wearing of masks during riots and "illegal demonstrations." Wearing a mask during a raucous protest henceforth could be a criminal offence leading to five years in prison. The law was introduced as a private member's bill, and was presented by its Conservative proponents as being necessary to protect public order from masked rioters, who might try to conceal their identity. ${ }^{47}$ It was argued that the law responded to the disorders associated with the protest at the G20 meeting in Toronto in 2010, and the Stanley Cup riots in Vancouver in 2011. In parliamentary debates, opposition members from the New Democratic Party (NDP) and Liberal Party raised objections about the potential impact on civil liberties, where masks might be worn for reasons other than inciting violence. Although the draft law stated that there might be a "lawful excuse" for covering one's face, it was not clear what constituted a "lawful excuse."48 In the Senate debate, the Senator who introduced the bill claimed that it would not apply to the niqab. ${ }^{49}$ Another Senator wondered how 
viable it would really be for a person to be prosecuted simply for covering his or her face, ${ }^{50}$ echoing the debate in France about whether the niqab ban could realistically be enforced. Yet as Senator Serge Joyal pointed out in the debate in Canada's Senate, the Montreal by-law was in the process of being challenged in court. ${ }^{51}$ Since Montreal (Quebec's largest city) and Canada as a whole had passed controversial decisions on the wearing of face coverings during protests, this created a political discourse politicizing face coverings and identifying them with resistance. Indeed, the PQ began floating the idea of the Charter not long after Bill C -309 was passed.

The fact that France had adopted legislation was used as one of the arguments in favour of Bill C-309, thereby showing the existence of a global debate on face coverings. Hence, the idea of limiting face coverings gained influence across transnational boundaries, in which once adopted in one context, laws were serving as role models for other countries' governments. As the above discussion showed, legislative debates in France and Québec referenced each other's decisions, while Russia's discussion also referred to the case of France. In defence of the proposed Charter of Values in Québec, a member of the Parti Québécois (and Cabinet Minister) argued in the legislature that similar laws had been adopted in France as well as other European countries. ${ }^{52}$ Considering the differences between the three countries, debates showed some striking similarities in discourse. Notwithstanding the objections, a parliamentary majority passed a sweeping law in France. In 2014, a more fragile government in Québec attempted to follow a path that resembled that of France, even when it was clear that such a law would bring difficult consequences.

In Québec and in France, soft-nationalist parties pursued these laws in a determined manner, typical of "wedge politics." The fact that both Sarkozy and the PQ suffered electoral defeats suggests the limits of this type of politics. In Québec, the fact that the Liberal government had previously initiated a more nuanced effort to build consensus on the issue may help to explain why the PQ had more difficulty than France's UMP did in putting its vision into law. However, the similarities between the discourses of France and Russia on headscarves ought to give Western politicians pause, as it suggests that there is some policy convergence between authoritarian states and democracies.

The evidence in this paper suggests that minority rights continue to be fragile in a number of states. As a numerically small population in Russia, France, and Québec, it is difficult for Muslim women to challenge such policies on their own. One of the most compelling arguments against restrictions on head and face coverings is the notion that such policies do not help women to achieve equality. A study of Muslim women in the United States (a slight majority of which did not wear the hijab) found that a substantial number said they had experienced discrimination. Some participants told interviewers that wearing a hijab could make one vulnerable to discrimination or unwelcome comments (Reeves, McKinney and Azam 2013, 56-60). Another study, carried out in a French suburb, found that many Muslim women who wore hijab participated actively in the civic life of their communities, and that restrictions on head coverings were more likely to impede women's participation than to facilitate it (Selby 2012). One wonders why politicians are so interested in what women wear. It was after all only in 2013 that it became legal for French women to wear trousers in public: they had been banned since 1800 (BBC News 
Europe 2014). Apparently, liberal democracies have not reached a consensus about when it is appropriate for the state to legislate on dress codes, especially those that apply to women.

\section{Endnotes:}

Note: For space reasons, references in some endnotes have been abbreviated. See list of references (following endnotes) for fuller reference, including Web addresses where indicated. The list of references provides a single Web address for each of the bills 94 and 60 (Quebec National Assembly), Loi 2010-1192 (French National Assembly), and C309 (Canadian Parliament), a link from which the Web address can be found for any endnotes that refer to those particular bills in the respective legislatures. Those endnotes conclude simply with "Web," and the reader can refer to the list of references for the link. In endnotes that reference those parliaments on other matters, the full Web address is provided within the text of the endnote.

${ }^{1}$ European Court of Human Rights. Case of Dogru vs. France, application no. 27058/05; Affaire Kervanci vs. France, requête no. 31645/04; 4 December 2008. Web.

2 République Française, Assemblée Nationale. "Proposition de résolution sur l'attachement au respect des valeurs républicaine face au développement de pratiques radicales qui y portent atteinte.” 27 April 2010. Web.

${ }^{3}$ République Française, Assemblée Nationale. Projet de loi 2520. "Projet de loi interdisant la dissimulation du visage dans l'espace public.” 19 May 2010. Dossier Legislatif, Loi no. 2010-1192. Web.

${ }^{4}$ Assemblée Nationale, "Projet de loi interdisant la dissimulation du visage dans l'espace public." Étude d'impact, May 2010, http://www.assemblee-nationale.fr/13/projets/pl2520-ei.asp accessed 18 June 2012.

5 Assemblée Nationale. République Française. Compte-rendu intégral (hereafter C-RI). 6 July 2010. Unless otherwise specified, complete Web references for the Compte-rendu intégral of the French National Assembly can be found below under References : I - Primary Source Documents, Dossier Legislatif, Loi no. 2010-1192.

${ }^{6}$ Assemblée Nationale. République Française. C-RI. 7 July 2010. Web.

${ }^{7}$ Assemblée Nationale. République Française. C-RI. 13 July 2010. Web.

${ }^{8}$ République Française. Sénat. Compte-rendu analytique officiel, 14 September 2010. Web.

${ }^{9}$ République Française. Décision no 2010-613 of the Conseil Constitutionnel (Constitutional Council). 7 October 2010. Web.

${ }^{10}$ European Court of Human Rights, Grand Chamber decision (Strasbourg) Case of S.A.S. vs France, application no. 43835/11. 1 July 2014.

${ }_{11}$ Assemblée Nationale du Québec, $39^{\text {th }}$ legislature, $1^{\text {st }}$ session, Projet de loi no. 94, "Loi établissant les balises encadrant les demands d'accomodement dans l'Administration gouvernmentale et dans certains établissements." (text of the draft law). Web.

12 Assemblée Nationale du Québec, Journal des débats de l'Assemblée Nationale (hereafter JDAN) 41 (98), 24 March 2010. Web.

${ }^{13}$ Assemblée Nationale du Québec, JDAN, 41, (170), 9 February 2011. Web.

${ }^{14}$ Assemblée Nationale du Québec, JDAN, 41 (170), 9 February 2011. Web.

15 Assemblée Nationale du Québec, JDAN, 41 (172), 15 February 2011. Web.

${ }^{16}$ Assemblée Nationale du Québec, JDAN 41 (172), 15 February 2011, p. 9013. Web. 
${ }^{17}$ Conseil du statut de la femme, Québec. "Memoire sur le projet de loi no. 94, Loi établissant les balises encadrant les demands d'accomodement dans l'administration gouvernmentale et dans certains établissements," May 2010. www.assnat.qc.ca/fr/travaux-parlementaires/commissions/CI/mandats/Mandat12329/memoires-deposes.html

accessed 24 June 2013.

${ }^{18}$ Federation des Canadiens Musulmans. "Pour un Québec inclusif et rassembleur: le projet de loi 94 est préjudiciable envers les Québécois(es) de confession musulmane." Mémoire presenté a l'Assemblée Nationale du Québec, May 2010, www.assnat.qc.ca/fr/travauxparlementaires/commissions/CI/mandats/Madat-12329/memoires-deposes.html accessed 24 June 2013.

${ }^{19}$ Assemblée Nationale du Québec, Commission des Institutions, Journal des débats de la Commission des Institutions (hereafter JDCI), 42 (2), 16 March 2011. Web.

${ }^{20}$ Assemblée Nationale du Québec, Commission des Institutions, JDCI, 42 (4), 29 March 2011. Web.

${ }^{21}$ Assemblée nationale du Québec, Commission des Institutions, JDCI 42 (5), 30 March 2011. Web.

${ }^{22}$ Assemblée Nationale du Québec, Commission des Institutions, JDCI, 42 (5), 30 March 2011. Web.

${ }^{23}$ Assemblée Nationale du Québec, Commission des Institutions, JDCI 42 (6), 31 March 2011, (7) 6 April 2011, and (8), 3 May 2011.

${ }^{24}$ Assemblée Nationale du Québec, Commission des Institutions, JDCI 42, 18, 3 May 2011; and (34), 28 September 2011. Web.

${ }^{25}$ Assemblée Nationale du Québec, Commission des Institutions, JDCI 42 (21), 18 May 2011. Web.

${ }^{26}$ Assemblée Nationale du Québéc, $40^{\text {th }}$ parlement, $1^{\text {st }}$ session, JDAN, 43 (82), 23 October 2013, http://www.assnat.qc.ca/fr/travaux-parlementaires/assemblee-nationale/40-1/journal-

debats/20131023/98991.html

accessed 18 March 2015 and 43 (89) 8 November 2013. http://www.assnat.qc.ca/fr/travaux-

parlementaires/assemblee-nationale/40-1/journal-debats/20131107/100389.html

accessed 18 March 2015.

Web.

${ }^{27}$ Remarks of Jean-Marc Fournier, in Assemblée Nationale du Québéc, $40^{\text {th }}$ parlement, $1^{\text {st }}$ session, JDAN 43 (89), 7 November 2013. Web.

${ }^{28}$ Assemblée Nationale du Québéc, 40 ${ }^{\text {th }}$ parlement, 1-re session, Procès-verbal No $.82,23$ October 2013, pp. 5107-5110, 5114-15, http://www.assnat.qc.ca/fr/travaux-parlementaires/assemblee-nationale/401/journal-debats/20131023/98991.html

Accessed 26 November 2014.

${ }^{29}$ Assemblée Nationale du Québéc, 40 ${ }^{\text {th }}$ parlement, $1^{\text {st }}$ session, Projet de loi 60, "Charte affirmant les valeurs de laïcité et de la neutralité réligieuse de l'État ainsi que d'égalité entre les femmes et less hommes et encadrant les demandes d'accomodement," (text of bill). Web.

${ }^{30}$ Remarks of Marc Tanguay, Assemblée Nationale du Québéc, $40^{\text {th }}$ parlement, $1^{\text {st }}$ session, Journal des débats de la Commission des institutions, vol. 43, no. 110, 23 January 2014, http://www.assnat.qc.ca/fr/travaux-parlementaires/commissions/ci-40-1/journal-debats/CI-140114.html Accessed 18 March 2015.

${ }^{31}$ Supreme Court of Canada, R. vs. N.S., 2012 SCC 72, 20 December 2012.

${ }^{32}$ Verkhovnyi Sud Rossiiskoi Federatsii (Supreme Court of the Russian Federation), hereafter VSRF, "Reshenie ot 5 marta 2003 n. ГКПИ03-76." Web.

${ }^{33}$ VSRF, "Opredelenie ot 15 maia 2003 g. N. KAC03-166. Web.

34 "Tekst prigovora uchasnitsam gruppy 'Pussy Riot." ("Text of the Verdict to the participants in the 'Pussy Riot' group") http://slon.ru/russia/prigovor_pussy_riot-821705.xhtml accessed 8 July 2013.

${ }^{35}$ Russian Federation Federal law 273-FZ “Ob obrazovanii v Rossiiskoi Federatsii,” 29 December 2012.

36 "Vy znaete, ved' v nashei kul'ture (kogda ia govoriu - nashei, ia imeiu v vidu traditsionnyi islam) nikakikh hidzhabov net.... A my u sebia budem vnedriat' chuzhdye nam traditsii - zachem?" Vladimir Putin, Press conference, Stenogramma (in Russian). 20 December 2012.

http://www.kremlin.ru/transcripts/17173

Accessed 9 July 2013. 
37 "Priamaia liniia s Vladimirom Putinym," Stenogramma. 25 April 2013. Moscow. http://kremlin.ru/news/17976 accessed 9 July 2013.

${ }^{38}$ VSRF, Opredelenie delo 19-АГП13-2. 10 July 2013.

${ }^{39}$ Draft law (zakonoproekt) no. 265406-6, presented to Duma 18 December 2013. Web.

${ }^{40}$ Remarks by O.V. Timofeeva, Stenogramma zasedanii (hereafter SZ) 18 December 2013. Web.

${ }^{41}$ M.V. Degtiarev, remarks in Gosudarstvennaia Duma, SZ, 18 December 2013. Web.

${ }^{42}$ Gosudarstvannaia Duma, SZ, 23 May 2014, Web. Federal'nyi zakon Rossiiskoi Federatsii ot 4 iuniia 2014 N. 148-FZ “O vnesenii izmenenii v Federal'nyi zakon ‘ob obrazovanii v Rossiiskoi Federatsii,"” Rossiiskaia gazeta, 6 June 2014.

${ }^{43}$ Gosudarstvannaia Duma, SZ 22 May 2012, Web.

${ }^{44}$ Gosudarstvennaia Duma, SZ, 22 May 2012, Web.

${ }^{45}$ France. "Décret no. 2009-724 du 19 juin 2009 relatif à l'incrimination de dissimulation illicite du visage à l'occasion de manifestations sur la voie politique." Web.

${ }^{46}$ Ville de Montréal, by-law 12-024,18 May 2012.

${ }^{47}$ Blake Edwards, Member of Parliament, remarks upon introducing Bill C-309, Parliament of Canada, House of Commons. $41^{\text {st }}$ parliament, $1^{\text {st }}$ session, edited Hansard, 025, 3 October 2011. Web.

${ }^{48}$ Parliament of Canada, House of Commons. Bill C-309. Second reading. $41^{\text {st }}$ parliament, $1^{\text {st }}$ session, edited Hansard, 048, 17 November 2011. Web.

${ }^{49}$ Senate of Canada, $41^{\text {st }}$ Parliament, $1^{\text {st }}$ session, Hansard, 148 (126) 5 December 2012. Web.

${ }^{50}$ Senator Mobina Jaffer, in Senate, $41^{\text {st }}$ Parliament, v1 ${ }^{\text {st }}$ session, 148, (126), 6 February 2013, www.parl.gc.ca/Content/Sen/Chamber/411/Debates/134db_2013-02-06-e.htm?Language=E\#49

Accessed 24 June 2013.

${ }^{51}$ Senator Serge Joyal. Senate, $1^{\text {st }}$ session, $41^{\text {st }}$ Parliament, 148 (165), 23 May 2013. Web.

${ }_{52}$ Assemblée Nationale du Québéc, $40^{\text {th }}$ parliament, 1st session, Procès-verbal No $.82,23$ October 2013, p. 5118. http://www.assnat.qc.ca/fr/travaux-parlementaires/assemblee-nationale/40-1/journaldebats/20131023/98991.html

Accessed 26 November 2014. 


\section{REFERENCES}

\section{Primary Source Documents}

Canada. Parliament of Canada. Legisinfo. $41^{\text {st }}$ Parliament, $1^{\text {st }}$ session. Bill C-309. House of Commons (Hansard), Senate (Hansard).

http://www.parl.gc.ca/LegisInfo/BillDetails.aspx?Language=E\&Mode=1 \&billId=513669 1 Accessed 8 May 2015.

Canada. Supreme Court of Canada, R. vs. N.S., 2012 SCC 72, 20 December 2012, http://scc.lexum.org/decisia-scc-csc/scc-csc/scc-csc/en/item/12779/index.do Accessed 25 July 2013.

European Court of Human Rights. Case of Dogru vs. France, application no. 27058/05; Affaire Kervanci vs. France, requête no. 31645/04; both Judgments Strasbourg, 4 December 2008. Web. http://hudoc.echr.coe.int/sites/eng/pages/search.aspx\# Accessed 23 January 2014.

- Case of S.A.S. vs France, application no. 43835/11. Grand Chamber decision (Strasbourg), 1 July 2014, http://hudoc.echr.coe.int/ Accessed 17 November 2011.

Québec. Assemblée Nationale du Québec, $39^{\text {th }}$ legislature (parlement), $1^{\text {st }}$ session. Étapes de cheminement du projet de loi no. 94. (Stages of progress of bill no. 94, 2010-2011). http://www.assnat.qc.ca/fr/travaux-parlementaires/projets-loi/projet-loi-94-39-1.html Accessed 8 May 2015.

. Assemblée Nationale du Québéc, $40^{\text {th }}$ legislature, $1^{\text {st }}$ session, Étapes de cheminement du projet de loi 60, "Charte affirmant les valeurs de laïcité et de la neutralité réligieuse de l'État ainsi que d'égalité entre les femmes et less hommes et encadrant les demandes d'accomodement," http://www.assnat.qc.ca/fr/travaux-parlementaires/projets-loi/projetloi-60-40-1.html

- Assemblée nationale du Québec, Commission des Institutions, Journal des débats de la Commission des Institutions. Web addresses for Commission documents relevant to Projet de loi no. 94 (39th legislature, 1st session: 2011 ) can be found at http://www.assnat.qc.ca/fr/travaux-parlementaires/projets-loi/projet-loi-94-39-1.html

Web addresses for Commission documents relevant to Projet de loi 60 (40th legislature, 1st session: 2014) can be found at http://www.assnat.qc.ca/fr/travauxparlementaires/projets-loi/projet-loi-60-40-1.html Accessed 18 March 2015.

République Française. Assemblée Nationale. "Proposition de résolution sur l'attachement au respect des valeurs républicaine face au développement de pratiques radicales qui y portent atteinte." $27 \quad$ April 2010. $\quad$ http://www.assembleenationale.fr/13/propositions/pion2455.asp Accessed 18 June 2012. 
Assemblée Nationale. Projet de loi 2520. "Projet de loi interdisant la dissimulation du visage dans l'espace public." Assemblée Nationale, 19 May 2010, http://www.assembleenationale.fr/13/projets/pl2520.asp Accessed 23 July 2013.

Assemblée Nationale. XIII Legislature. Dossier Legislatif. Loi no. 2010-1192 du 11 october 2010 interdisant la dissimulation du visage dans l'espace public. http://www.assemblee-nationale.fr/13/dossiers/dissimulation_visage_espace_public.asp Accessed 8 May 2015.

. Conseil Constitutionnel. Décision no 2010-613. 7 October 2010 http://www.conseilconstitutionnel.fr/decision//2010/2010-613-dc/decision-n-2010-613-dc-du-07-octobre2010.49711.html Accessed 17 July 2010.

. "Décret no. 2009-724 du 19 juin 2009 relatif à l'incrimination de dissimulation illicite $\mathrm{du}$ visage à l'occasion de manifestations sur la voie politique," http://legifrance.gouv.fr/affichTexte.do?cidTexte=JORFTEXT000020763885\&fastPos=1 $\underline{0 \text { \&fastReq } I d=1787566938 \& \text { categorieLien }=i d \& o l d A c t i o n}=$ rechTexte Accessed 3 June 2013.

- Sénat. Compte-rendu analytique officiel, 14 septembre 2010. http://www.senat.fr/seances/s201009/s20100914/st20100914000.html Accessed 23 July 2013.

Rossiiskaia Federatsiia (Russian Federation). President. http://www.kremlin.ru

Rossiiskaia Federatsiia (Russian Federation). Federalnoe Sobranie, Gosudarstvennaia Duma. (Federal Assembly, State Duma). Stenogramma zasedanii. http://transcript.duma.gov.ru/

- Federalnoe Sobranie, Gosudarstvennaia Duma. (Federal Assembly, State Duma). Draft law (zakonoproekt) no. 265406-6, “O vnesenii izmenenii v Federal'nyi zakon 'ob obrazovanie v Rossiiskoi Federatsii," presented to Duma 18 December 2013. Web. http://asozd2.duma.gov.ru Accessed 22 December 2013.

Rossiiskaia Federatsiia (Russian Federation). "Tekst prigovora uchasnitsam gruppy 'Pussy Riot." ("Text of the Verdict to the participants in the 'Pussy Riot' group") http://slon.ru/russia/prigovor_pussy_riot-821705.xhtml Accessed 8 July 2013.

Rossiiskaia Federatsiia (Russian Federation). Verkhovnyi Sud Rossiiskoi Federatsii (Supreme Court of the Russian Federation), "Reshenie ot 5 marta 2003 n. ГКПИ03-76," http://www.sudbiblioteka.ru/vs/text_big2/verhsud_big_25918.htm Accessed 16 April 2012. 
23 Review of European and Russian Affairs 9 (2), 2015

- "Opredelenie ot 15 maia 2003 g. N. KAC03-166, http://www.sudbiblioteka.ru/vs/text_big2/verhsud_big_27874.htm Accessed 16 April 2012.

—. "Opredelenie delo 19-АГП13-2.” 10 July 2013.

http://www.supcourt.ru/stor_pdf.php?id=549010 Accessed 18 March 2015.

Rossiiskaia Federatsiia (Russian Federation). Federal law 273-FZ “Ob obrazovanii v Rossiiskoi Federatsii," 29 December 2012.

http://publication.pravo.gov.ru/Document/View/0001201212300007 Accessed 18 March 2015.

. Federal'nyi zakon Rossiiskoi Federatsii ot 4 iuniia 2014 N. 148-FZ "O vnesenii izmenenii v Federal'nyi zakon 'ob obrazovanii v Rossiiskoi Federatsii," Rossiiskaia gazeta, 6 June 2014. http://www.rg.ru/2014/06/06/forma-dok.html

Ville de Montréal, by-law 12-024, passed 18 May 2012.

http://ville.montreal.qc.ca/portal/page?_pageid=3619,4034063\&_dad=portal\&_schema= PORTAL Accessed 18 March 2015.

\section{Secondary Sources}

Adrian, Melanie "A Common Life amist Fragmentation: a Consideration of German and French Approaches to the Integration of Muslims," Journal of Muslim Minority Affairs, vol. 31, no. 3, 2011, pp. 411-22.

Afshar, Haleh. "The Politics of Fear: What does it mean to those who are Otherized and Feared?" Ethnic and Racial Studies, vol. 36, no. 1, January 2013, pp. 9-27.

Ahmed, Leila. A Quiet Revolution: the Veil's Resurgence from the Middle East to America. New Haven, CT: Yale University Press, 2011.

Alekhina, Marina. "Zaiiavlenie - k obvineniiu," 31 July 2012, http://echo.msk.ru/blog/alekhina/914624-echo/ Accessed 31 July 2012.

Arat, Yeşim. "Religion, Politics and Gender Equality in Turkey: Implications of a Democratic Paradox," Third World Quarterly, vol. 31, no. 6, 2010, pp. 869-84.

Associated Press, "Russia Security Forces Look for Suicide Bombers before Games," January 21, 2014. http://www.cbc.ca/news/world/russia-security-forces-look-for-suicidebombers-before-games-1.2504643 Accessed 22 January 2014. 
BBC News Europe, "Paris Women Finally Allowed to Wear Trousers," 4 February 2014, http://www.bbc.com/news/world-europe-21329269 Accessed 6 May 2014.

Barry, Ellen. "Local Russian Hijab Ban puts Muslims in a Squeeze," New York Times, 18 March 2013, http://www.nytimes.com/2013/03/19/world/europe/russian-regions-hijab-ban-putssqueeze-on-muslims.html?pagewanted=all\&_r=0 Accessed 23 July 2014.

Borghée, Maryam. Voile intégrale en France: Sociologie d'un paradox. Paris: Éditions Michalons, 2012.

Bouchard, Gerard and Charles Taylor, Building the Future: a Time for Reconciliation. Gouvernement du Québec. Commission de Consultation sur les pratiques d'accomodement reliées aux differences culturels, 2008.

Bowen, John R. Why the French Don't Like Headscarves: Islam, the State and Public Space, Princeton, NJ: Princeton University Press, 2007.

Bustikova, Lenka and Herbert Kitschelt, "The Radical Right in Post-Communist Europe: Comparative Perspectives on Legacies and Party Competition," Communist and PostCommunist Studies, vol. 42, 2009, 459-83.

Camus, Elvire. "Voile intégral: un loi difficilement applicable." Le Monde, 2 August 2014. http://www.lemonde.fr/societe/article/2013/08/02/voile-islamique-une-loi-difficilementapplicable 3455937_3224.html Accessed 18 March 2015.

CBC News, "Québec's Culture Clash," 23 May 2008, http://www.cbc.ca/news/canada/story/2008/05/21/f-minority-accommodation.html Accessed 24 July 2013.

Chen, Mel. "Masked States and the 'Screen' between Security and Disability," Women's Studies Quarterly, vol. 40, nos. 1 and 2 (spring/summer 2012), pp. 79-96.

Chrisafis, Angelique. "Firmly Faithful to the Niqab," The Guardian Weekly, vol. 185, no. 17, 713 October 2011, pp. 25-7.

- "France's headscarf law: 'it's an attack on freedom'," 22 July 2013, www.guardian.co.uk/world/2013/jul/22/frances-headscarf-war-attack-on-freedom Accessed 22 July 2013.

—. "Pussy Riot protesters arrested in Marseille." Guardian, 19 August 2012, http://www.guardian.co.uk/world/2012/aug/19/pussy-riot-protesters-arrested-marseille Accessed 21 August 2012.

Eichler, Maya. "A Gendered Analysis of the Chechen Wars," International Feminist Journal of Politics, vol. 8, no. 4, December 2006, pp. 486-511. 
European Court of Human Rights, Press release, 165 (2013) 30 May 2013.

Fedosenko, Vladimir. "Khidzhab v shkolu ne poidet," Rossiiskaia gazeta, 11 June 2013, http://www.rg.ru/2013/07/10/pravo-site.html Accessed 18 March 2015.

Fredette, Jennifer. Constructing Muslims in France: Discourse, Public Identity and the Politics of Citizenship. Philadelphia: Temple University Press, 2014.

Gerin, André (Chair). Rapport d'Information, Au nom de la Mission d'Information sur la pratique $d u$ port de la voile intégrale sur le territoire national, no. 2262, http://www.assemblee-nationale.fr/13/rap-info/i2262.asp Accessed 19 June 2012.

Ghodsee, Kristen. "Headscarves in Homeroom: Women's Islamic Dress in the 'New' Europe," AAASS Newsnet, vol. 47, no. 4, August 2007, 1-6.

Ghodsee, Kristen. Muslim Lives in Eastern Europe: Gender, Ethnicity and the Transformation of Islam in Postsocialist Bulgaria Princeton, NJ: Princeton University Press, 2010.

Gougou, Florent and Simone Labouret. "La fin de la tripartition? Les recompositions de la droite et la transformation du système partisan," Revue française de science politique, vol. 63, no. 2, April 2013, pp. 279-304.

Hancock, Ange-Marie. "When Multiplication doesn't equal Quick Addition: Examining Intersectionality as a Research Paradigm," Perspectives on Politics, vol. 5, no. 1, March 2007, pp. 63-79.

Hébert, Chantal. "Marois burned by her own scorched-earth politics," Chronicle Herald 3 April 2014 http://thechronicleherald.ca/opinion/1197819-h-bert-marois-burned-by-her-ownscorched-earth-politics Accessed 6 May 2014.

Hillygus, D. Sunshine and Todd G. Shields, The Persuadable Voter: Wedge Issues in Presidential Campaigns. Princeton, NJ: Princeton University Press, 2008.

Höjelid, Stefan. "Headscarves, Judicial Activism and Democracy: the 2007-8 Constitutional Crisis in Turkey," The European Legacy, vol. 15, no. 4, 2010, pp. 467-82.

Human Rights Watch. You Dress According to their Rules: Enforcement of an Islamic Dress Code for Women in Chechnya. March 2011. http://www.hrw.org/reports/2011/03/10/youdress-according-their-rules-0 Accessed 23 July 2014.

IPSOS-Mori, "Perils of Perception," October 29, 2014. https://www.ipsosmori.com/researchpublications/researcharchive/3466/Perceptions-are-not-reality-Thingsthe-world-gets-wrong.aspx Accessed 24 March 2015. 
Jeong, Gyung-Ho, Garry J. Miller, Camilla Schofield and Itai Sened, "Cracks in the Opposition: Immigration as a Wedge Issue for the Reagan Coalition." American Journal of Political Science, vol. 55, no. 3, July 2011, pp. 511-25.

Kaldor, Mary and Sabine Selchow, "The 'Bubbling up' of Subterranean Politics in Europe," Journal of Civl Society, vol. 9, no. 1, 2013, pp. 78-99.

Kaya, Ayhan. "Backlash of Multiculturalist and Republicanist Policies of Integration in the Age of Securitization," Philosophy and Social Criticism, vol. 38, nos. 4-5, 2012, pp. 399-401.

Kazempur, Abdolmohammad. The Muslim Question in Canada: a Story of Segmented Integration. Vancouver, BC: UBC Press, 2014.

Kizenko, Nadieszda "Feminized Patriarchy?" Orthodoxy and Gender in Post-Soviet Russia," Signs, vol. 38, no. 3, spring 2013 pp. 595-621.

Leane, Geoffrey W.G. "Rights of Ethnic Minorities in Liberal Democracies: Has France Gone too Far in Banning Muslim women from Wearing the Burka?" Human Rights Quarterly, vol. 33, no. 4, November 2011, pp. 1032-61.

Lemay, Violaine and Marie-Neige Lapierre, "Student Protests and Government Somersaults: the Québec Spring from a Law and Society Perspective." Canadian Journal of Law and Society, vol. 27, no. 3, 2012, pp. 439-50.

Maddison, Sarah. "Ideas from 'across the ditch,': Wedge Politics in the 2005 New Zealand Election, Australian Journal of Political Science, vol. 41, no. 3, September 2006, 427-35.

Massell, Gregory J. The Surrogate Proletariat: Moslem Women and Revolutionary Strategies in Soviet Central Asia, 1919-29 Princeton, NJ: Princeton University Press, 1974.

Muxel, Anne. "La Mobilisation Électorale de 2012." Review française de science politique, vol. 63, no. 2, April 2013, pp. 207-24.

Nadeau, Richard and Michael S. Lewis-Beck, "French Election Theory: Why Sarkozy Lost," Parliamentary Affairs, vol. 66, no. 1, January 2013, pp. 52-68.

Nicholson, Stephen P., Voting the Agenda: Candidates, Elections and Ballot Propositions. Princeton, NJ: Princeton University Press, 2005.

Petzen, Jennifer. "Contesting Europe: a Call for an Anti-Modern Sexual Politics," European Journal of Women's Studies, vol. 19, no. 1, 2012, pp. 97-114.

Pew Research Center, "A Fragile Rebound for EU Image on Eve of European Parliament Elections," 12 May 2014. http://www.pewglobal.org/files/2014/05/2014-05-12_PewGlobal-Attitudes-European-Union.pdf Accessed 24 March 2015. 
RAPSI, "Russian Parents Appeal Hijab Ban in Upper Court," RIA-Novosti, 22 April 2013, http://en.rian.ru/russia/20130422/180783267.html Accessed 24 July 2014.

Reeves, Terrie C., Arlise P. McKinney and Laila Azam, "Muslim Women's Workplace Experiences: Implications for Strategic Diversity Initiatives," Equality, Diversity and Inclusion, vol. 32, no. 1, 2013, pp. 49-67.

Selby, Jennifer A. Questioning French Secularism: Gender Politics and Islam in a Parisian Suburb, New York, NY: Palgrave Macmillan, 2012.

Shadid, W. and P. S. Von Koningsveld, "Muslim Dress in Europe: Debates on the Headscarf," Journal of Islamic Studies, vol. 16, no. 1 (2005), pp. 35-61.

Stack, Alisa. "Zombies versus Black Widows: Women as Propaganda in the Chechen Conflict" in Laura Sjoberg and Caron E. Gentry, eds. Women, Gender and Terrorism. Athens, GA: University of Georgia Press, 2011, pp. 83-95.

Stasiulis, Daiva. "Worrier Nation: Québec's Value Codes for Immigrants," Politikon, vol. 40, no. 1, 2013, pp. 183-209.

Tarlo, Emma. Visibly Muslim: Fashion, Politics, Faith. Oxford, UK and New York, NY: Berg Publishers, 2010.

Tarrow, Sidney. Power in Movement: Social Movements and Contentious Politics. $3^{\text {rd }}$ edition. Cambridge and New York: Cambridge University Press, 2011.

Thomas, Elaine R. Immigration, Islam and the Politics of Belonging in France: a Comparative Framework. Philadelphia, PA: University of Pennsylvania, 2012.

Tiberj, Vincent. "Values and the Votes from Mitterand to Hollande: the Rise of the Two-Axis Politics," Parliamentary Affairs, vol. 63, no. 2, April 2013, pp. 69-86.

Watson, Peggy. "The Rise of Masculinism in Eastern Europe," New Left Review, no. 198, March/April 1993, pp. 71-82.

Wayland, Sarah V. "Religious Expression in Public Schools: kirpans in Canada, hijab in France," Ethnic and Racial Studies, vol. 20, no. 3, July 1997, pp. 545-62.

Wells, Paul. "Is Le Tea Party Over? It's up to PQ." Macleans, 7 April 2014, http://www.macleans.ca/politics/ottawa/is-le-tea-party-over-its-up-to-pq/ Accessed 6 May 2014.

Wilson, Shaun and Nick Turnbull. "Wedge Politics and Welfare Reform in Australia." Australian Journal of Politics and History, vol. 47, no. 3, September 2001, 384-404. 
Wolchik, Sharon L. "Putinism under Siege: Can there be a Color Revolution?" Journal of Democracy, vol. 23, no. 3, July 2012, pp. 63-70.

Wood, Tony. "Collapse as Crucible: The Reforging of Russian Society," New Left Review, no. 74, March-April 2012, pp. 5-38. 
Published by the Centre for European Studies at Carleton University, Ottawa, Canada Available online at: journals.carleton.ca/rera/index.php/rera

RERA is an electronic academic peer-reviewed journal that publishes graduate, postgraduate, and young scholarly works. Topics relate to the European Union, its Member States, the former Soviet Union, and Central and Eastern Europe. The journal is a joint project supported by the Canada-Europe Transatlantic Dialogue - a cross-Canada research network supported by the Social Sciences and Humanities Research Council of Canada (SSHRC) - along with the Institute of European, Russian and Eurasian Studies (Carleton University) and its associated research unit, the Centre for European Studies.

RERA aims to provide an accessible forum for research, to promote high standards of research and scholarship, and to foster communication among young scholars.

\section{Contact:}

Carleton University

The Centre for European Studies

1103 Dunton Tower

1125 Colonel By Drive

Ottawa, ON K1S 5B6

Canada

Tel: +01 613 520-2600 ext. 3117; E-mail: rera-journal@ carleton.ca

\section{Creative Commons License}

\section{(ㅇ) $\odot \Theta \Theta$}

creativecommons.org/licenses/by-nc-nd/3.0

This Working Paper is licensed under a Creative Commons Attribution-NonCommercial-

No Derivs 3.0 Unported License (CC BY-NC-ND 3.0).

Articles appearing in this publication may be freely quoted and reproduced, provided the source is acknowledged. No use of this publication may be made for resale or other commercial purposes.

ISSN: 1718-4835

(C) 2015 The Author 